\title{
Future Environments for Europe: Some Implications of Alternative Development Paths
}

W.M. Stigliani, F.M. Brouwer, R.E. Munn, R.W. Shaw, and M. Antonovsky

EXECUTIVE REPORT 15

February 1989

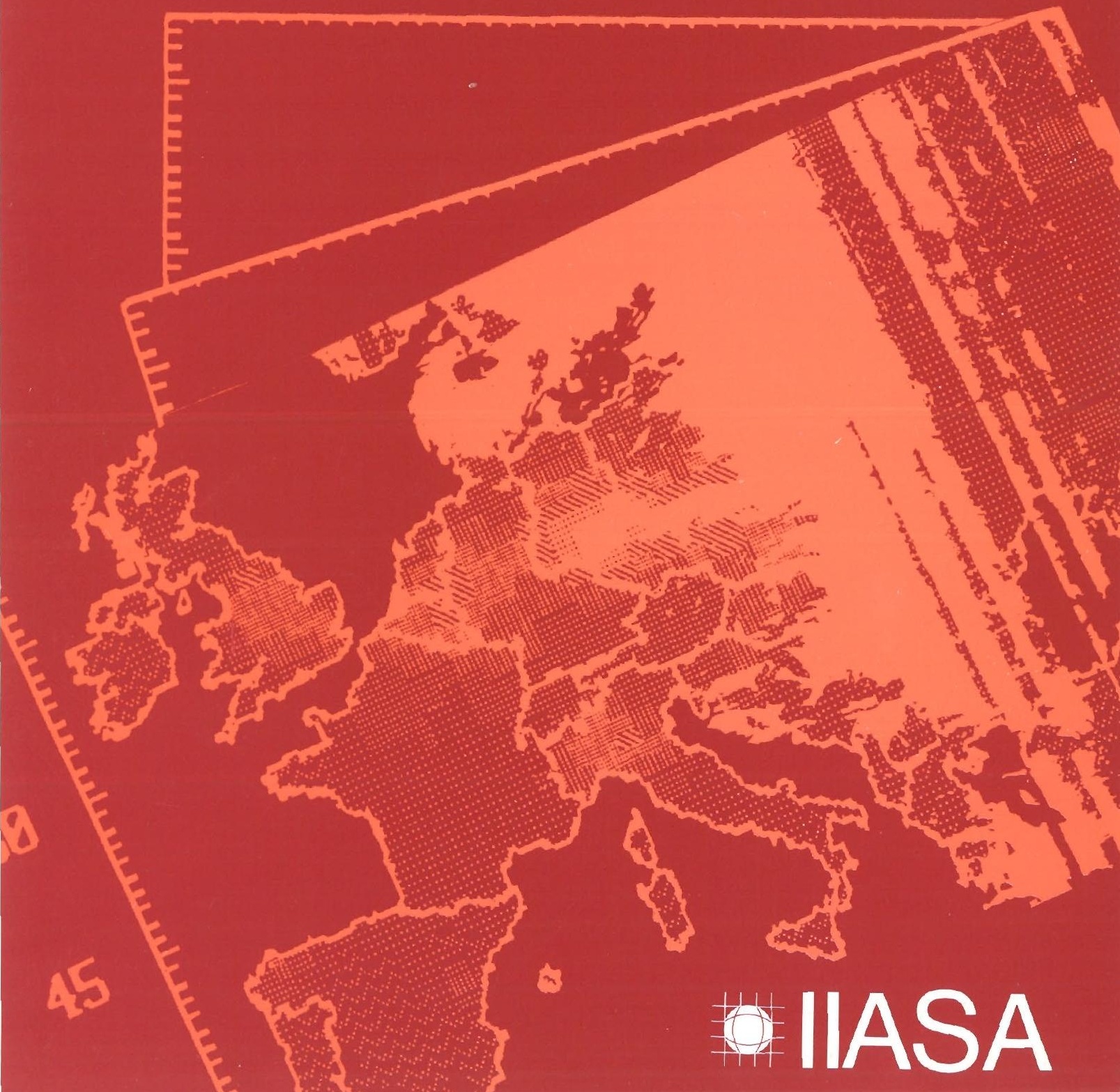



FUTURE ENVIRONMENTS FOR EUROPE:

SOME IMPLICATIONS OF

ALTERNATIVE DEVELOPMENT PATHS

W.M. Stigliani, F.M. Brouwer, R.E. Munn,

R.W. Shaw, and M. Antonovsky

International Institute for Applied Systems Analysis

Laxenburg, Austria

Executive Report 15

February 1989

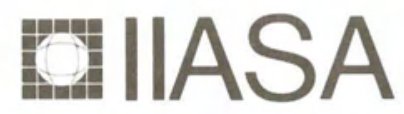

INTERNATIONAL INSTITUTE FOR APPLIED SYSTEMS ANALYSIS

Laxenburg, Austria 
International Standard Book Number 3-7045-0093-3

Executive Reports, which summarize research conducted at IIASA, are independently reviewed before publication. However, the views and opinions they express are not necessarily those of the National Member Organizations or other institutions that support IIASA's work.

Copyright (C) 1989

International Institute for Applied Systems Analysis

All rights reserved. No part of this publication may be reproduced or transmitted in any form or by any means, electronic or mechanical, including photocopy, recording, or any information storage or retrieval system, without permission in writing from the publisher.

Cover design by Martin Schobel

Printed by Novographic, Vienna, Austria 


\section{Foreword}

With the completion of the Report of the World Commission on Environment and Development (popularly known also as the Brundtland Commission Report) in 1987, and the subsequent worldwide attention given to that study, the concept of ecologically sustainable development has gained broad recognition. It is now commonly acknowledged that economic development and ecological sustainability are not contradictory goals. To the contrary, they are interdependent - the economy of a country cannot grow over the long term, when its environment is being hopelessly degraded, and a country experiencing severe ecological degradation cannot restore its environment without developing economically. Most of the focus of ecologically sustainable development has been on the less developed countries in Latin America, Africa, and Asia. Because of the desperate straits of the populations in those areas, such focus is certainly merited.

Our IIASA study, focused on Europe, had at its inception in 1985 two goals. The first was methodological. We reasoned that if in fact it were possible to conduct a study of European environmental problems 40 years into the future, perhaps similar studies could be conducted for the less developed continents. We believe that this European "experiment" has been successful and we strongly support the undertaking of "future environments" studies elsewhere in the world.

The second goal was one of substance. What precisely could we learn about the major environmental problems that could confront future generations of Europeans, and how would we begin to solve those problems now, rather than bequeathing them, in their most severe manifestations, to our children and grandchildren? We also believe we have succeeded, at least in part, in realizing this goal.

I am pleased, therefore, to introduce this very important study for I believe it will be a major contribution to the ongoing effort to achieve an ecologically sustainable world.

I would also like to single out for special praise the study's two sponsors, the Ministry of Housing, Physical Planning, and the Environment, Leidschendam, The Netherlands, and the Ministry of the Environment, Prospective 
Group, Paris, France, who had the wisdom and foresight in 1985 to understand the potential importance of this study, and without whose support and constant encouragement we would not have been able to complete it.

B.R. Döös

Leader

Environment Program 


\section{Major Findings}

- Because of the linkages between the European and global environments, sustaining the European environment in the 21st century cannot be fully achieved without sustaining the global environment.

- The continuation of present trends in economic development and environmental protection in Europe and elsewhere is not sufficient to prevent further deterioration of the European environment.

- High economic growth in Europe and elsewhere without adequate environmental protection accompanying such growth will lead to even more severe environmental problems.

- Environmentally friendly development in Europe offers the hope of mitigating local and regional-scale problems specific to Europe.

- But these actions, in and of themselves, cannot solve problems within Europe stemming from global-scale changes. To accomplish the latter, the rest of the world must also follow environmentally friendly pathways.

- Thus, European nations should do all in their power to enact environmentally friendly development both in Europe and in the rest of the world.

The unabridged report, for which this publication is the Executive Summary, will be published by Elsevier in May 1989 in the journal The Science of the Total Environment. 



\section{Contents}

Foreword iii

Major Findings $\quad$ v

1. The Global Problem 1

2. The European Problem 2

3. Major Findings 3

4. The Role of Scenarios and Models in Managing an Uncertain Future 8

5. A Glimpse of Possible European Environmental Futures 8

6. General Recommendations on Policies Appropriate for $\begin{array}{lr}\text { Sustaining the European Environment } & 15\end{array}$

Acronyms 



\section{FUTURE ENVIRONMENTS FOR EUROPE: SOME IMPLICATIONS OF ALTERNATIVE DEVELOPMENT PATHS}

\section{The Global Problem}

In spite of enormous advances in our ability to understand, interpret, and ultimately manage the natural world, we approach the 21 st century in awesome ignorance of what is likely to unfold, in terms of both the human activities that affect the environment and the responses of the earth to those activities. One certain fact is that the planet will be subjected to pressures hitherto unprecedented in its evolutionary history. The world's population is likely to grow from 5 to 8.2 billion within 35 years. Over this same time period, energy consumption could easily double relative to 1980 , food production must increase by $3 \%$ to $4 \%$ yearly, and general economic activities could grow up to fivefold (report of the World Commission on Environment and Development).

Moreover, "tomorrow's world" will not simply be an inflated version of "today's world" with more people, more energy consumption, more industry, and so on. Rather, the world of the 21st century will be qualitatively different from today in at least three important respects. First, new technologies will transform the relationship of man to the natural world. In the positive sense, industry will pass from an emphasis on products to be manufactured to an emphasis on functions to be performed. A prime example is the gradual transition from an agriculture heavily dependent on chemicals to one that is essentially biologically intensive through the application of biotechnologies. In the negative sense, the release of bioengineered organisms may pose new kinds of risks if the development and use of such organisms are not carefully controlled.

The second major change differentiating tomorrow's world from today's is climatic change. Owing to the accumulation of greenhouse gases in the atmosphere, average annual global temperatures are expected to increase to levels 
higher than at any time over the last 200,000 years. And yet even the most advanced climate models currently cannot predict how regional and continental climates will change.

Third, society has moved beyond the era of localized and relatively simple environmental problems. What were once local incidents of pollution shared throughout a common watershed or air basin now involve many nations. What were once acute, short-lived episodes of reversible damage now affect many generations. What were once straightforward questions of conservation versus development now reflect complex linkages. These problems will become more pronounced over the next century, as society enters an era of increasingly complex patterns of interdependence of the global economy and the world environment.

Relative to earlier generations of problems, these emerging patterns of interaction are characterized by profound scientific ignorance, enormous decision costs, and temporal and spatial scales transcending those of most contemporary political and regulatory institutions.

\section{The European Problem}

The European environment is tightly linked to the global environment by global systems such as climate and stratospheric ozone. Typically, such linkages are reciprocal in nature - European activities affect the global environment, and what happens outside of Europe affects the European environment. Moreover, European supply and demand for natural resources are linked to global supply and demand. Thus, for example, the use of European land for wood production will depend to a large degree on the availability (or lack thereof) of global forest supplies. Hence, the problem of managing the European environment must be viewed within the context of the global environment.

However, it is important to note that not all of Europe's problems are global ones; European societies can do much to put their house in order regardless of what is occurring on the global scale. Effects such as acid deposition and the buildup and release of toxic materials are essentially regional- and continentalscale problems. Although even these are coupled to climate by complex feedbacks, their solutions depend explicitly on European actions to mitigate these effects.

IIASA's report on the "Future Environments for Europe: Some Implications of Alternative Development Paths" provides new insights into the problems of managing the European environment during an era of fundamental transitions in technologies, climate, and scale of effects. The focus is on ecologically sustainable development, in terms of both the opportunities afforded to European societies in seeking to achieve it and the constraints imposed on development by the slow adaptive capacities of ecological systems. The time scale of the study is approximately the next 40 years. However, because solutions to most of the problems require decades of planning, actions must be taken over the short term. 


\section{Major Findings}

\subsection{Implications of alternative socioeconomic development pathways}

Approaching environmental sustainability in Europe in the 21st century depends on fundamental societal choices that will have to be made in the next several decades. Will European societies embark on sociopolitical and economic development pathways that are inherently "environmentally friendly?" Or will they only pay lip service to major environmental concerns as they strive for economic growth and undergo rapid social and political changes?

Our report analyzes the environmental implications of four alternative socioeconomic development pathways with respect to 11 environmental issues (termed policy dilemmas) that could become major problems in the future. The policy dilemmas include:

- Managing water resources in an era of climate change.

- Acidification of soils and lakes in Europe.

- Long-term forestry management and the possibility of a future shortfall in wood supply.

- Areas of Europe marginalized by mainstream economic and agricultural development.

- Sea level rise.

- Chemical pollution of coastal waters.

- Toxic materials buildup and the potential for chemical time bombs.

- Non-point-source emissions of potentially toxic substances.

- Transportation growth versus air quality.

- Decreasing multi-functionality of land owing to urban and suburban land development.

- Increasing summer demand for electricity, and the impact on air quality.

The four alternative socioeconomic development pathways entail:

(1) Present trends continuing in Europe and elsewhere, i.e., slow economic growth and modest success in slowing down environmental change, implying a moderate climate warming by the year 2030 .

(2) High-growth economy in Europe and elsewhere, with only lip service being paid to the environment, implying a strong climate warming by the year 2030.*

(3) Environmentally friendly economy in Europe and elsewhere, with only slight climate change by the year 2030 .

(4) Environmentally friendly economy in Europe but not elsewhere, where there is high economic growth without adequate environmental protection, implying a strong climate warming [as in pathway (2)].

\footnotetext{
*As noted in the Brundtland Commission Report, poverty is a major cause of environmental degradation, especially in the less developed countries. Hence, the assumption made here is that high economic growth and ecological sustainability are incompatible only when societies are not willing to enact the appropriate measures necessary for sustaining the environment.
} 
Table 1 lists, for each development pathway and each dilemma, a ranking represented by green, yellow, or red. Also, the rankings of the dilemmas in the 1980s are given. The key to the rankings is as follows:

$\begin{array}{ll}\text { green: } & \text { not serious } \\ \text { yellow: } & \text { moderately serious } \\ \text { red: } & \text { very serious }\end{array}$

The relative preponderance of green and yellow rankings assigned to the environment of the 1980s should not be interpreted as signifying that the current European environment is without major problems. Rather, it suggests that with respect to the dilemmas chosen, the potential major consequences have yet to be experienced. In fact, the dilemmas were specifically selected as problems for the future, rather than those that are currently fully manifested.

Conclusions can be drawn for each pathway from Table 1 . One may observe that relative to the $1980 \mathrm{~s}$, pathway (1) (present trends continuing in Europe and elsewhere) would lead to a somewhat more degraded environment in 2030 , since all of the dilemmas except urbanization and summer oxidant episodes would become more serious. The dilemmas are somewhat tempered by only moderate European climate change.

Pathway (2) (high-growth economy in Europe and elsewhere, low environmental concern) would lead to strong deterioration with respect to all dilemmas. Some of the degradation is related to specific European activities, which would cause increased consumption of natural resources, as well as increased chemical inputs to the environment. Broad-scale, strong climatic change creates problems related to water management, sea level rise, and summer oxidant episodes, and global deforestation affects forestry wood supply.

Pathway (3) (environmentally friendly economy in Europe and elsewhere) is the only one for which the dilemmas are largely solved, although the problem of transport growth would remain owing to the rapid increase in demand in air travel.

Pathway (4) (environmentally friendly economy in Europe but not elsewhere) is particularly interesting because it addresses the important question of the linkages of the European environment to the global environment. It thus represents the optimal degree to which Europe can protect its environment when high-growth, non-sustainable development is occurring in the rest of the world. Compared with pathway (2), the worst-case scenario, one may observe that Europe definitely would benefit from an environmentally friendly pathway.

A final point that should be made with respect to Table 1 concerns the near equivalence of yellow and red rankings for pathways (1) and (4) (present trends continuing in Europe and elsewhere versus an environmentally friendly Europe but not elsewhere). In both cases, very serious problems arise by the year 2030 but they are different:

Pathway (1) (moderate climate warming) soil acidification

transport growth
Pathway (4) (strong climate warming) water management

forestry wood supply sea level rise 
Table 1. Ranking of dilemmas for the 1980s and according to development path for the year 2030. Green, yellow, and red indicate not serious, moderately serious, and very serious, respectively.

\begin{tabular}{|c|c|c|c|c|c|}
\hline Dilemma & $1980 s$ & $\begin{array}{l}\text { Pathway (1) } \\
\text { Present } \\
\text { trends } \\
\text { continuing } \\
\text { Europe and } \\
\text { elsewhere } \\
\end{array}$ & \begin{tabular}{|l|} 
Pathway (2) \\
High- \\
growth \\
economy/low \\
env. concern \\
Europe and \\
elsewhere \\
\end{tabular} & $\begin{array}{l}\text { Pathway (\$) } \\
\text { Environ- } \\
\text { mentally } \\
\text { friendly } \\
\text { economy } \\
\text { Europe and } \\
\text { elsewhere } \\
\end{array}$ & $\begin{array}{l}\text { Pathway (4) } \\
\text { Environ- } \\
\text { mentally } \\
\text { friendly } \\
\text { economy } \\
\text { Europe but } \\
\text { not elsewhere }\end{array}$ \\
\hline $\begin{array}{l}\text { Water } \\
\text { manage- } \\
\text { ment }\end{array}$ & & & & & \\
\hline $\begin{array}{l}\text { Soil } \\
\text { acidifi- } \\
\text { cation }\end{array}$ & & & & & \\
\hline $\begin{array}{l}\text { Forestry } \\
\text { wood } \\
\text { supply }\end{array}$ & & & & & \\
\hline $\begin{array}{l}\text { Margin- } \\
\text { alized } \\
\text { land }\end{array}$ & & & & & \\
\hline $\begin{array}{l}\text { Coastal iss } \\
\text { - Sea level } \\
\text { - Pollutior }\end{array}$ & & & & & \\
\hline $\begin{array}{l}\text { Chemical } \\
\text { time } \\
\text { bombs }\end{array}$ & & & & & \\
\hline $\begin{array}{l}\text { Non-point } \\
\text { toxics }\end{array}$ & & & & & \\
\hline $\begin{array}{l}\text { Transport } \\
\text { growth }\end{array}$ & & & & & \\
\hline $\begin{array}{l}\text { Urbani- } \\
\text { zation }\end{array}$ & & & & & \\
\hline $\begin{array}{l}\text { Summer } \\
\text { oxidant } \\
\text { episodes }\end{array}$ & & & & & \\
\hline
\end{tabular}


Hence, it should not be construed from Table 1 that pathways (1) and (4) are more or less equivalent with respect to overall environmental impact. In fact, if a fifth development pathway were envisaged, present trends continuing in Europe but with strong climate warming, its number of red (very serious) rankings would be more than the three associated with pathway (4).

\subsection{Ordering the seriousness of the dilemmas}

Another important and related question is within each development path which dilemmas are most serious? Table 2 provides an answer to that question, showing the dilemmas that ought to be of most concern for Europeans for each of the four development paths. First, it is apparent that the ordering of the dilemmas changes from one pathway to another, and this undoubtedly would cause problems in the formulation of policies expected to be robust over a range of development pathways. Second, Table 2 reemphasizes a point made earlier, viz., that the seriousness of the environmental problems facing Europe in the year 2030 depends on two factors:

- Failure to take effective global actions to control greenhouse gases and deforestation, development pathways (2), (4), and to some extent (1), leading to very serious problems with respect to water management, forestry wood supply, and sea level rise.

- Failure to take effective European actions to control local and regional environmental degradation, development pathways (1) and (2), leading to very serious problems with respect to soil acidification and transport growth.

Pathway (2) is the worst, combining failures to take both global and European actions. This leads not only to the five problems listed above but also to three additional very serious ones: chemical time bombs, non-point source toxics, and summer oxidant episodes.

In summary, the major findings of the study are presented in the list below:

- Because of the linkages between the European and global environments, sustaining the European environment in the 21st century cannot be fully achieved without sustaining the global environment.

- The continuation of present trends in economic development and environmental protection in Europe and elsewhere is not sufficient to prevent further deterioration of the European environment.

- High economic growth in Europe and elsewhere without adequate environmental protection accompanying such growth will lead to even more severe environmental problems.

- Environmentally friendly development in Europe offers the hope of mitigating local and regional-scale problems specific to Europe.

- But these actions, in and of themselves, cannot solve problems within Europe stemming from global-scale changes. To accomplish the latter, the rest of the world must also follow environmentally friendly pathways. 
Table 2. Ranking of the dilemmas for the 1980 s and for each development path for the year 2030 .

\begin{tabular}{|c|c|c|c|}
\hline Pathway & Very serious & Moderately serious & Not serious \\
\hline $1980 \mathrm{~s}$ & & $\begin{array}{l}\text { Soil acidification } \\
\text { Transport growth } \\
\text { Summer oxidants }\end{array}$ & $\begin{array}{l}\text { Water management } \\
\text { Forestry wood supply } \\
\text { Marginalized land } \\
\text { Sea level } \\
\text { Coastal pollution } \\
\text { Chemical time bombs } \\
\text { Non-point toxics } \\
\text { Urbanization }\end{array}$ \\
\hline $\begin{array}{l}\text { Present trends } \\
\text { continuing } \\
\text { Europe and } \\
\text { elsewhere }\end{array}$ & $\begin{array}{l}\text { Soil acidification } \\
\text { Transport growth }\end{array}$ & $\begin{array}{l}\text { Water management } \\
\text { Forestry wood supply } \\
\text { Marginalized land } \\
\text { Sea level } \\
\text { Coastal pollution } \\
\text { Chemical time bombs } \\
\text { Non-point toxics } \\
\text { Summer oxidants }\end{array}$ & Urbanization \\
\hline $\begin{array}{l}\text { High-growth } \\
\text { economy/ } \\
\text { low environ- } \\
\text { mental concern } \\
\text { Europe and } \\
\text { elsewhere }\end{array}$ & $\begin{array}{l}\text { Water management } \\
\text { Soil acidification } \\
\text { Forestry wood supply } \\
\text { Sea level } \\
\text { Chemical time bombs } \\
\text { Non-point toxics } \\
\text { Transport growth } \\
\text { Summer oxidants }\end{array}$ & $\begin{array}{l}\text { Marginalized land } \\
\text { Coastal pollution } \\
\text { Urbanization }\end{array}$ & \\
\hline $\begin{array}{l}\text { Environmentally } \\
\text { friendly economy } \\
\text { Europe and } \\
\text { elsewhere }\end{array}$ & & Transport growth & $\begin{array}{l}\text { Water management } \\
\text { Soil acidification } \\
\text { Forestry wood supply } \\
\text { Marginalized land } \\
\text { Sea level } \\
\text { Coastal pollution } \\
\text { Chemical time bombs } \\
\text { Non-point toxics } \\
\text { Urbanization } \\
\text { Summer oxidants }\end{array}$ \\
\hline $\begin{array}{l}\text { Environmentally } \\
\text { friendly economy } \\
\text { Europe but } \\
\text { not elsewhere }\end{array}$ & $\begin{array}{l}\text { Water management } \\
\text { Forestry wood supply } \\
\text { Sea level }\end{array}$ & $\begin{array}{l}\text { Marginalized land } \\
\text { Chemical time bombs } \\
\text { Transport growth } \\
\text { Urbanization } \\
\text { Summer oxidants }\end{array}$ & $\begin{array}{l}\text { Soil acidification } \\
\text { Coastal pollution } \\
\text { Non-point toxics }\end{array}$ \\
\hline
\end{tabular}


- Thus, European nations should do all in their power to enact environmentally friendly development both in Europe and in the rest of the world.

\section{The Role of Scenarios and Models in Managing an Uncertain Future}

To understand the larger purpose of our study, it is necessary to stress two important distinctions. One is that, as a fundamental premise, we assume that management of long-term environmental problems can be improved despite considerable uncertainties that will continue to thwart the formulation of detailed predictions of future environments. A second point is the distinction we have drawn between the role of scenarios and that of forecasting models. Planning based on mathematical forecasts can be reasonably accurate during relatively stable time periods. But precisely for that reason, models will fail when they are most needed: in anticipating fundamental changes that require a new paradigm in planning for the future. Another important point is that the need for personal judgement is not eliminated by models. Indeed, if models are used merely to provide the answers, then the decision maker has in effect abdicated much of his power to the model builders.

The scenario approach adopted in our study offers an alternative method for managing an uncertain future. Scenarios are the bridge between facts and perceptions; their role is to enhance a decision maker's understanding of the future by providing perceptions of alternative future environments against which decisions can be tested. The goal is not to predict the future, but rather to learn to live with uncertainty, to factor it into the decision process, and to improve the quality of thinking among decision makers.

Advocating such an approach in no way reduces the value of modeling. On the contrary, the complexities of the real world are such that without some assistance in organizing this complexity, policymakers are increasingly helpless and are forced to make decisions without any real idea of the consequences. The distinction, however, is that the models must be judged not by the criterion of how accurately they can reveal actual future trajectories. Rather, they should be judged by how useful they are in enhancing the decision maker's knowledge and understanding by exploring the dynamic consequences of some of the complex assumptions.

\section{A Glimpse of Possible European Environmental Futures}

The problem facing European societies is how to choose a pathway that optimizes both protection of the environment and socioeconomic development. It is not unlike a driver lost at an intersection, faced with the choice of proceeding in three different directions without a map available to provide guidance. The driver can not travel down several pathways simultaneously; a choice must be made, despite the uncertainties. However, what about the roads not taken? What opportunities were lost by not traveling down a particular road? What 
problems were avoided? One major role of scenarios is to provide some insights into such questions.

To illustrate the point, three dilemmas are highlighted here, viz., soil acidification, chemical time bombs, and climate (as related to water management, sea level rise, and feedbacks to other dilemmas). Acid deposition is currently the most serious environmental consequence of energy use in Europe. Resulting from emissions of sulfur and nitrogen oxides during the combustion of fossil fuels, it causes soil acidification over extensive regions of Europe. Once soils acidify, a cascade of negative effects follows, including loss of the capacity ts buffer against additional acidic inputs, losses of nutrients, reduced biologica activity, leaching of toxic metals, acidification of lakes, and degradation 0 . aquatic habitats.

A chemical time bomb is a metaphor describing the propensity for certair man-made chemicals to accumulate over years and decades in ecological system: with no seemingly adverse effects, until some threshold for storing the chemica is reached. At that time, a sudden - and often surprising - release of the chemi cal to the wider environment may occur, often resulting in a serious environmen tal effect. When considering the environmental impacts of technologies tha release such chemicals to the environment, time-delayed effects are rarely fore seen (witness, for example, the depletion of the ozone layer from chloro fluorocarbons). By the time the effects do become manifested and causally linked to a particular technology, it may be difficult to remedy the situatior because technologies tend to become entrenched over time.

Climate directly affects the hydrological cycle, which regulates the availability of water for societal uses. Sea level rise may cause serious problems for coastal areas. In addition, the entire biosphere has evolved by adapting to its abiotic environment, the most important factor of which is climate. Hence, it may be expected that there are important feedbacks between climate and many other environmental phenomena.

\subsection{Soil acidification}

Figures $1(a)$ and $1(b)$ show patterns of sulfur deposition in Europe in the year 2030 according to two different scenarios of fuel use. Figure 1(a) portrays the situation in which nuclear power is replaced by coal. The sulfur deposition flux exceeds four grams of sulfur per square meter per year in Central Europe and one gram of sulfur per square meter over most of Europe. Figure $1(b)$ demonstrates that if the energy system were based more upon natural gas or hydrogen (the latter produced without the combustion of sulfur-containing fuels), the maximum deposition flux would decrease to three or four grams of sulfur per square meter per year, and, generally, deposition would be less than one gram of sulfur per square meter per year in most of Europe. (Loads of sulfur considered to be deleterious to sensitive soils and aquatic ecosystems are estimated to be as low as 0.3 to $1.5 \mathrm{~g} \mathrm{~S} / \mathrm{m}^{2} / \mathrm{yr}$.) 


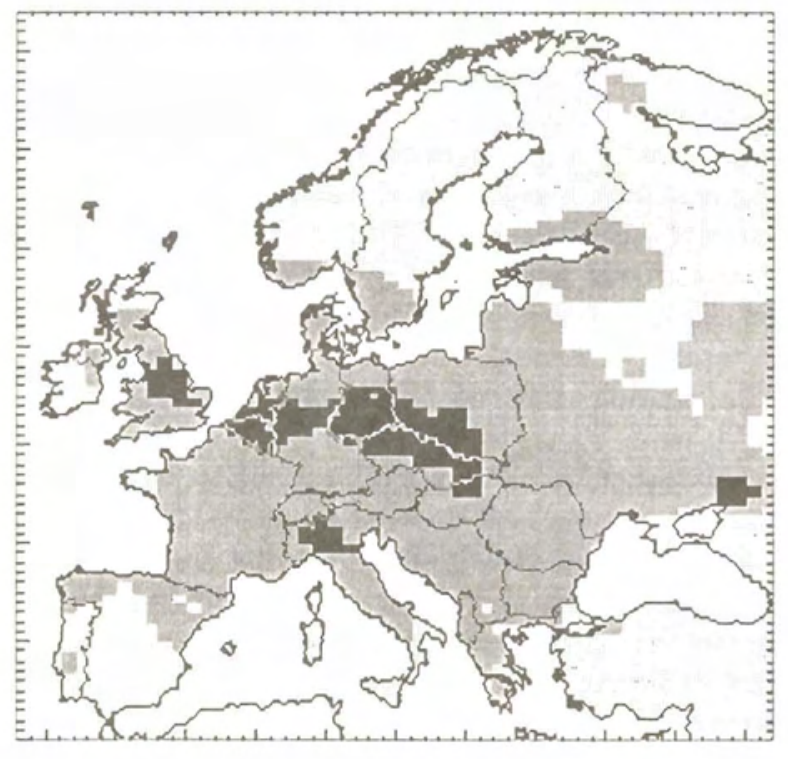

(a)

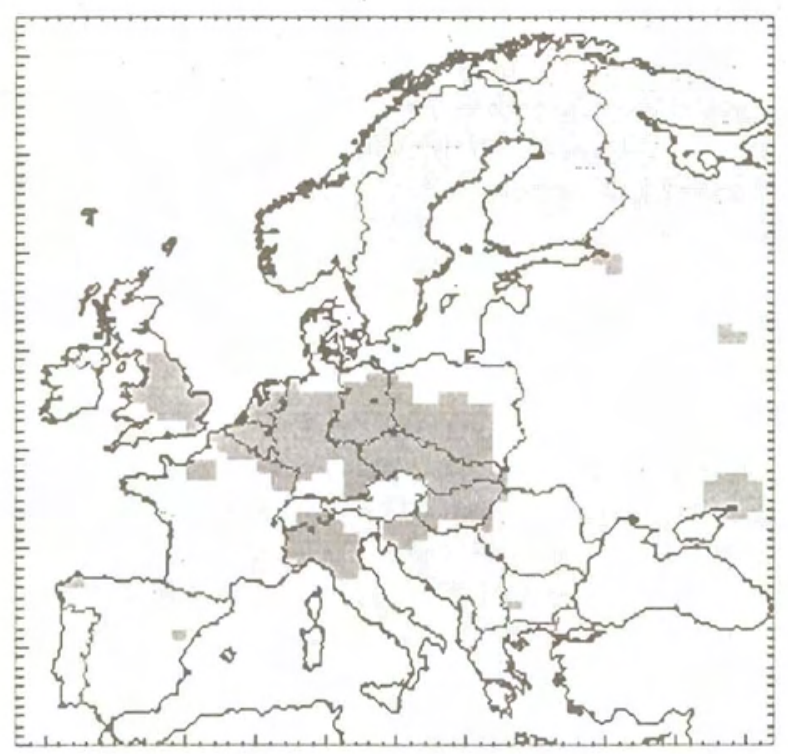

(b)

Figure 1. Total sulfur deposition $\left(\mathrm{g} / \mathrm{m}^{2} / \mathrm{yr}\right)$ for year 2030 for $\mathrm{SO}_{2}$ emissions assuming (a) nuclear power is replaced by coal and (b) an energy system based upon natural gas or hydrogen (the latter produced without combustion of sulfur-containing fuels). (Source: Transboundary Air Pollution Project, IIASA.) 
In terms of soil acidification in Central Europe (the Federal Republic of Germany, the German Democratic Republic, Poland, Czechoslovakia, Austria, and Hungary), the scenario depicted in Figure 1(a) would result in $40 \%$ of the forest soils having a pH less than 4.0. By comparison, the scenario shown in Figure $1(b)$ would result in only $15 \%$ of the forest soils having a $\mathrm{pH}$ of less than 4.0 . (A pH of 4.0 is critical because the full spectrum of negative effects is manifested at these $\mathrm{pH}$ levels.)

\subsection{Chemical time bombs}

Any chemical that tends to accumulate in an ecological system has a potential to cause deleterious and surprising environmental effects, if the system retaining the chemical has a limited capacity to do so. To use a simple analogy, such a system may be compared to a sponge and the accumulating chemical to water. The sponge will absorb water up to a point, after which it can no longer retain additional water. The time required to saturate the system can be years, decades, or even centuries in some cases. The accumulation of acid deposition in the soils of Europe began in the generation of our grandparents, and we are paying the price now in terms of continuing soil and lake acidification in extensive regions of Europe. Similarly, some of our activities undoubtedly are causing slow incremental alterations in the environment that may "explode" as full-blown environmental problems in the generation of our grandchildren.

Thus, in terms of sustaining the environment for future generations, it is important to identify potentially harmful chemicals that tend to accumulate in the environment, the kinds of ecological systems that tend to store them, and the threshold mechanisms by which they are released to the wider environment. In our report we have identified six such problems areas that may exhibit timebomb phenomena. These are shown in Table 3.

The worse effects of chemical time bombs can probably be prevented, but only if European societies choose to embark on an environmentally friendly pathway, which would include the following actions:

- Better early warning monitoring systems.

- Establishment of a European incidents registry, whose mission would be to record, analyze, and disseminate information on time-bomb-like episodes.

- More rigorous standards for premarket testing of potentially toxic substances.

- Establishment of source inventories and environmental pathways for each substance.

- Reductions in materials use through conservation and recycling.

\subsection{The climate connection}

Figures $\mathcal{2}(a), \mathcal{Z}(b), \mathcal{Z}(c)$, and $\mathcal{2}(d)$ depict two possible scenarios for average seasonal temperature changes in Europe. Figures $2(a)$ and $2(b)$ (based on historical analogues of European warm periods) show the changes that might be expected 
Table S. Chemical/ecosystem interactions as potential time bombs.

\begin{tabular}{|c|c|c|c|}
\hline Ecological system & Chemical stored & Threshold mechanism & Delayed effect \\
\hline Forest soils & $\begin{array}{l}\text { Acids (from } \\
\text { deposition) }\end{array}$ & $\begin{array}{l}\text { Depletion of buffering } \\
\text { capacities }\end{array}$ & $\begin{array}{l}\text { Acidification of } \\
\text { soils and lakes; } \\
\text { leaching of heavy } \\
\text { metals }\end{array}$ \\
\hline $\begin{array}{l}\text { Agricultural } \\
\text { soils }\end{array}$ & $\begin{array}{l}\text { Phosphate } \\
\text { fertilizer }\end{array}$ & $\begin{array}{l}\text { Saturation of } \\
\text { phosphate sorption } \\
\text { capacities }\end{array}$ & $\begin{array}{l}\text { Leaching of } \\
\text { phosphate to aquatic } \\
\text { systems (eutrophi- } \\
\text { cation) }\end{array}$ \\
\hline $\begin{array}{l}\text { Agricultural } \\
\text { soils (aban- } \\
\text { doned) }\end{array}$ & $\begin{array}{l}\text { Heavy metals } \\
\text { (e.g., Cd) }\end{array}$ & $\begin{array}{l}\text { Lowered sorption } \\
\text { capacities on ces- } \\
\text { sation of liming }\end{array}$ & $\begin{array}{l}\text { Leaching of metals } \\
\text { to water bodies; } \\
\text { plant uptake }\end{array}$ \\
\hline Coastal waters & a & $\begin{array}{l}\text { Depletion of oxygen; } \\
\text { generation of } \mathrm{H}_{2} \mathrm{~S} \text {; } \\
\text { mixing of deep water } \\
\text { during storm events }\end{array}$ & Anoxia, fish kills \\
\hline $\begin{array}{l}\text { Estuary } \\
\text { sediments }\end{array}$ & Heavy metals & $\begin{array}{l}\text { Changes in redox } \\
\text { potential; resus- } \\
\text { pension of sediments } \\
\text { (sea level rise) }\end{array}$ & $\begin{array}{l}\text { Release of metals; } \\
\text { fish poisoning }\end{array}$ \\
\hline Wetlands & $\begin{array}{l}\text { Sulfur; } \\
\text { heavy metals }\end{array}$ & $\begin{array}{l}\text { Drying from climate } \\
\text { change (causing ex- } \\
\text { posure to air) }\end{array}$ & $\begin{array}{l}\text { Release of sulfuric } \\
\text { acid; heavy metals }\end{array}$ \\
\hline
\end{tabular}

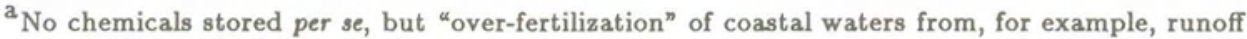
of agricultural fertilizers can lead to sudden episodes of anoxia and $\mathrm{H}_{2} \mathrm{~S}$ generation.

in the year 2030 under slight climatic change. The main features are slight to moderate warming in summer, and in winter, slight cooling in most of Europe, but slight warming in other parts. Such a scenario, however, is only plausible if there were to be a sharp global slowdown in the rates of emission of greenhouse gases. Required actions to achieve this result would include dramatic increases in energy efficiency globally and greatly expanded use of energy systems and technologies that do not generate $\mathrm{CO}_{2}$ or other greenhouse gases as waste products. Examples of the latter are the renewable energy sources (e.g., solar, wind, hydro, biomass) and nuclear energy.

In contrast, Figures $\mathscr{2}(c)$ and $\mathscr{2}(d)$ show how temperatures could be affected in the year 2030 in the case of no restriction in the emissions of greenhouse gases (i.e., if the equivalent concentration of $\mathrm{CO}_{2}$ were double that of today). One may notice that the magnitudes of the changes are substantially larger than those in Figures $\mathscr{2}(a)$ and $\mathscr{2}(b)$. Also, temperature increases are greater in Southern Europe in summer but greater in Northern Europe in the winter.

Accompanying changes in temperature will be changes in evapotranspiration and precipitation. This could result in increases or decreases in water availability. In either case water management strategies can no longer assume that the water supplies will be essentially constant in the future. 
Slight climatic change

(a) Summer

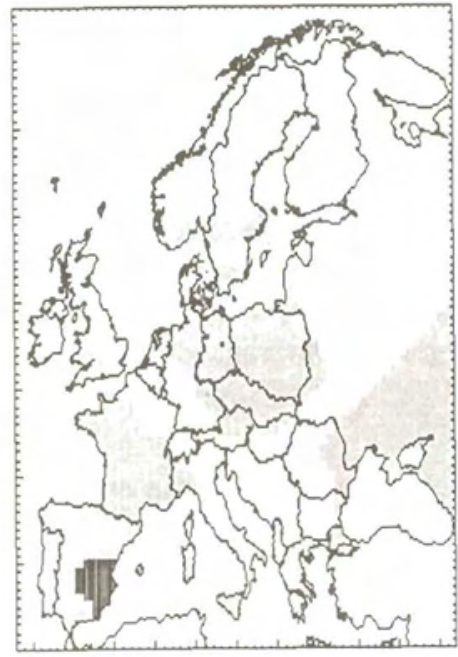

(b) Winter

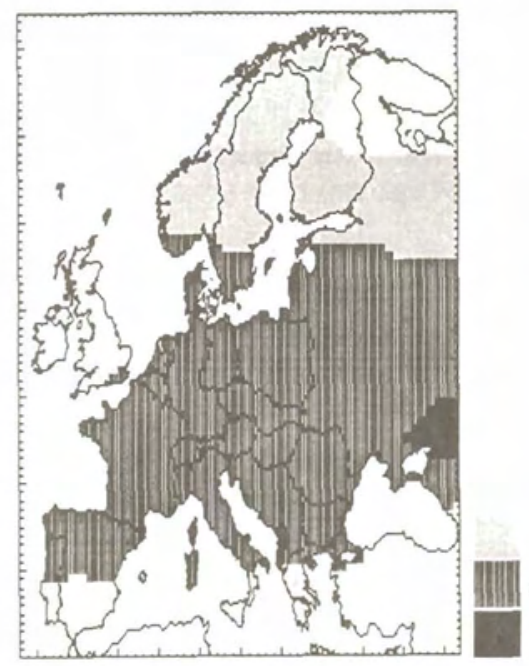

Strong climatic change

(c) Summer

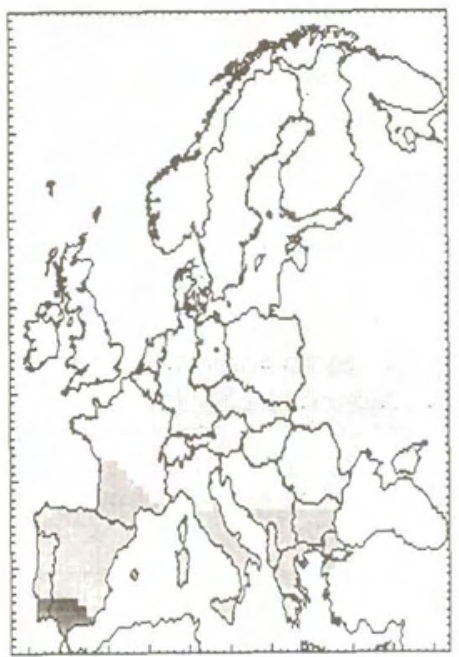

(d) Winter

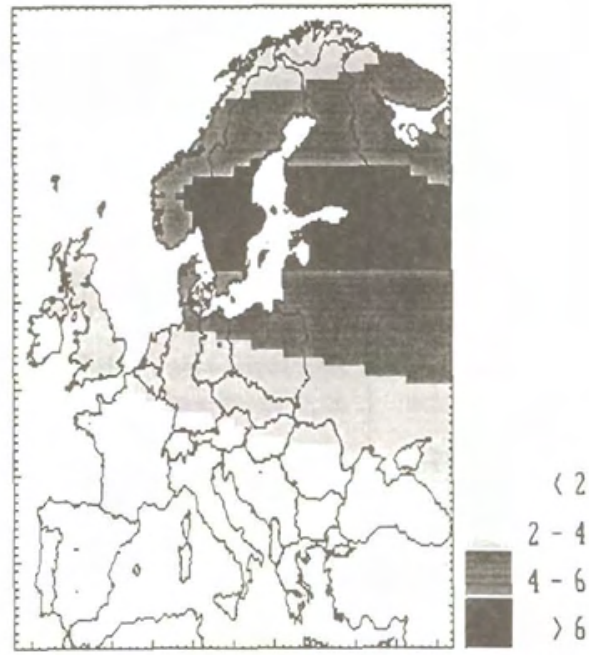

Figure 2. Projected changes of temperature (in ${ }^{\circ} \mathrm{C}$ ) in (a) summer (upper) and (b) winter (lower) for slight climatic change. [Based on historical analogues of European warm periods; adapted from J.M. Lough, T.M.L. Wigley, and J.P. Palutikof (1983) Journal of Climate and Applied Meteorology 22: 1673-1684.] Temperature increases expected in $(c)$ summer (upper) and (d) winter (lower) for strong climate change. [Based on equivalent doubling in concentration of $\mathrm{CO}_{2}$; adapted from J.F.B. Mitchell (1983) Quarterly Journal of the Royal Meteorological Society 109: 113-152.] 
Over and above these predicted changes, another important point is that most likely not only average temperatures and water availability will change, but also extreme events, e.g., droughts, floods, heat waves, and cold snaps, will occur more frequently. Increased variability in the water supply will make water management much more problematic in the future.

Sea level rise, expected from a strong climatic change will raise serious problems for European coastal areas. Especially at risk will be newly built touristic areas that lack institutional apparatus and revenues for coping with sea level rise.

In addition, strong climatic change will have secondary effects on most of the other dilemmas described in the study. Such linkages are given in Table 4, which also helps to illustrate one of the major conclusions of the study, viz., that the European environment is closely linked to the global environment - especially with respect to climatic change.

Table 4. Potential effects of a strong global climate warming on the European environment.

\begin{tabular}{|c|c|}
\hline Dilemma & Effect \\
\hline $\begin{array}{l}\text { Water } \\
\text { management }\end{array}$ & Large changes in water supply (both up and down) \\
\hline $\begin{array}{l}\text { Soil } \\
\text { acidification }\end{array}$ & $\begin{array}{l}\text { Changing weather patterns would change acid deposition patterns } \\
\text { (worse conditions in some areas, better conditions in others) }\end{array}$ \\
\hline $\begin{array}{l}\text { Forestry } \\
\text { wood } \\
\text { supply }\end{array}$ & $\begin{array}{l}\text { Increased temperatures, major changes in precipitation, seriously } \\
\text { stressing boreal forests }\end{array}$ \\
\hline $\begin{array}{l}\text { Marginalized } \\
\text { land }\end{array}$ & $\begin{array}{l}\text { Some areas may become unsuitable for current uses, owing to salt wa- } \\
\text { ter intrusions, latitudinal shifts in areas of optimal crop production, } \\
\text { etc. }\end{array}$ \\
\hline $\begin{array}{l}\text { Coastal } \\
\text { issues }\end{array}$ & $\begin{array}{l}\text { Sea level rise causing soil and groundwater salinization; flooding of } \\
\text { toxic waste dumps located near coasts }\end{array}$ \\
\hline $\begin{array}{l}\text { Chemical } \\
\text { time bombs }\end{array}$ & $\begin{array}{l}\text { Sea level rise mobilizing heavily polluted sediments with clean waters; } \\
\text { drying of wetlands causes release of many toxic materials }\end{array}$ \\
\hline $\begin{array}{l}\text { Non-point } \\
\text { toxics }\end{array}$ & Not greatly affected if recycling is effective \\
\hline $\begin{array}{l}\text { Transport } \\
\text { growth }\end{array}$ & No specific direct effects \\
\hline Urbanization & $\begin{array}{l}\text { Current urban land use in coastal and alpine regions may not be suit.- } \\
\text { able under changed climatic conditions }\end{array}$ \\
\hline $\begin{array}{l}\text { Summer } \\
\text { oxidant } \\
\text { episodes }\end{array}$ & $\begin{array}{l}\text { Increases in } \mathrm{NO}_{\mathrm{x}} \text { owing to increased demand for electricity, especially } \\
\text { in Southern Europe in summer for air-conditioning }\end{array}$ \\
\hline
\end{tabular}




\section{General Recommendations on Policies Appropriate for Sustaining the European Environment}

\subsection{Ecologically sustainable development as a conceptual framework for European environmental policy}

Ecologically sustainable development is defined by the World Commission on Environment and Development (Brundtland Commission) as "development that meets the needs of the present without compromising the ability of future generations to meet their needs." The first precondition in the search for sustainable development is for European societies to recognize that many of the major environmental issues facing Europe are long-term (e.g., half a century), largescale (continental to global), interconnected, and prone to surprises (chemical time bombs, for example).

The second precondition is that societies should develop a philosophy by which they are willing to sacrifice short-term gains (economic or otherwise) for the sake of long-term benefits for future generations. But this precondition can only be met if societies have sufficient information to recognize the need for sacrifice and if governments provide institutional means (incentives, for example) to ensure that people feel that they are being treated fairly. Within this framework, a number of general recommendations can be made.

\subsection{Promotion of environmentally friendly development in Europe and the world}

Europe. European societies must act to ensure that potential long-term, largescale environmental problems are addressed today so that they will not worsen in the future. With respect to the dilemmas discussed in this study, Table 5 lists examples of such actions.

The World. Within the various international forums available, European nations should use their influence to promote ecologically sustainable development in all parts of the world. This would include facilitation of the transfer of environmentally friendly technologies to the Third World and encouragement of actions such

as those indicated in Table 5. Even as a matter of self-interest, Europe should set an example in the reduction of emissions of greenhouse gases and should encourage other regions to do likewise.

\subsection{Involvement of citizens, the private sector, governments, and international organizations}

The public and private sectors, governments, and international organizations all have important roles to play in ensuring an environmentally friendly future. Above all, the public must become more environmentally conscious. Citizens must accept the stewardship of the environment as their personal responsibility. 
Table 5. Environmentally friendly mitigation actions.

\begin{tabular}{|c|c|}
\hline Dilemma & Action \\
\hline $\begin{array}{l}\text { Water } \\
\text { management }\end{array}$ & $\begin{array}{l}\text { Public acceptance of water-conservation practices; development and } \\
\text { implementation of water-saving technologies }\end{array}$ \\
\hline $\begin{array}{l}\text { Soil } \\
\text { acidification }\end{array}$ & $\begin{array}{l}\text { Large reductions in } \mathrm{SO}_{\mathrm{x}} \text { and } \mathrm{NO}_{\mathrm{x}} \text { emissions by implementation of } \\
\text { cleaning technologies }\end{array}$ \\
\hline $\begin{array}{l}\text { Forestry } \\
\text { wood supply }\end{array}$ & Reductions in ozone and acidity; long-term planning of timber harvest \\
\hline $\begin{array}{l}\text { Marginalized } \\
\text { lands }\end{array}$ & $\begin{array}{l}\text { Program for soil protection and landscape preservation, reforestation, } \\
\text { etc. }\end{array}$ \\
\hline $\begin{array}{l}\text { Coastal } \\
\text { issues }\end{array}$ & $\begin{array}{l}\text { Large reductions in runoff of } \mathrm{N}, \mathrm{P} \text { fertilizers; installation of sewage } \\
\text { treatment plants }\end{array}$ \\
\hline $\begin{array}{l}\text { Chemical } \\
\text { time bombs }\end{array}$ & $\begin{array}{l}\text { Introduction of early-warning monitoring systems; research into fac- } \\
\text { tors causing sudden chemical releases; establishing an international } \\
\text { "incidents registry" }\end{array}$ \\
\hline $\begin{array}{l}\text { Non-point } \\
\text { toxics }\end{array}$ & $\begin{array}{l}\text { Extensive recycling of commercial and domestic products; reduction of } \\
\mathrm{N}, \mathrm{P} \text { fertilizer runoff; use of environmentally friendly products; in- } \\
\text { tegrated pest management in agriculture }\end{array}$ \\
\hline $\begin{array}{l}\text { Transport } \\
\text { growth }\end{array}$ & Use of clean fuels and clean combustion technologies \\
\hline Urbanization & Long-term land-use planning with strong public support \\
\hline $\begin{array}{l}\text { Summer } \\
\text { oxidant } \\
\text { episodes }\end{array}$ & $\begin{array}{l}\text { Large reductions in } \mathrm{NO}_{\mathbf{x}} \text { and hydrocarbon emissions; energy conserva- } \\
\text { tion }\end{array}$ \\
\hline
\end{tabular}

They must view ecological sustainability and its fulfillment as an obligation to future generations. Personal actions might include: conservation of energy, water, and materials; recycling wastes; purchasing environmentally friendly products; and participation in consumer-related activities pertaining to environmental protection.

Before such a strong public commitment will occur, however, governments must strongly support environmental education programs that will sensitize the layman to the critical issues and motivate him to act. Another important governmental activity would be the provision of environmental information that permits citizens and the private sector to make environmentally sound decisions.

The private sector can do its share by conserving energy, water, and materials and reducing wastes in production processes; conducting environmental assessments of new technologies and products and giving higher priority to those deemed to be more environmentally benign; and actively promoting environmentally friendly products and technologies.

Governments have available a wide array of instruments for promoting improved environmental quality. Prohibition and regulation are two such instruments that have been widely incorporated with only limited success. Various tax 
incentives, pricing structures, effluent charges, international trade policies, and other mechanisms are available, and may be more effective in many cases.

International European organizations including the ECE, EEC, CMEA, EFTA, OECD, and WHO-Europe can play an important role in solving transboundary pollution problems. These organizations have worked effectively to solve short-term environmental problems. More emphasis could be placed on the integrated approach required to deal with the large-scale problems expected in the next 50 years.

In addition, the United Nations and international financial institutions such as the World Bank and the International Monetary Fund can play a large and crucially important role in promoting environmentally friendly development in the Third World. Because the global economy is so closely linked to the global environment, every effort must be made to proceed with ecological sustainability in the context of the global perspective.

\section{Acronyms}

CMEA Council for Mutual Economic Assistance

ECE United Nations Economic Commission for Europe

EEC European Economic Community

EFTA European Free Trade Association

IIASA International Institute for Applied Systems Analysis

OECD Organisation for Economic Co-operation and Development

WHO World Health Organization 




\section{|lIASA}

INTERNATIONAL INSTITUTE FOR APPLIED SYSTEMS ANALYSIS 2361 LAXENBURG, AUSTRIA 